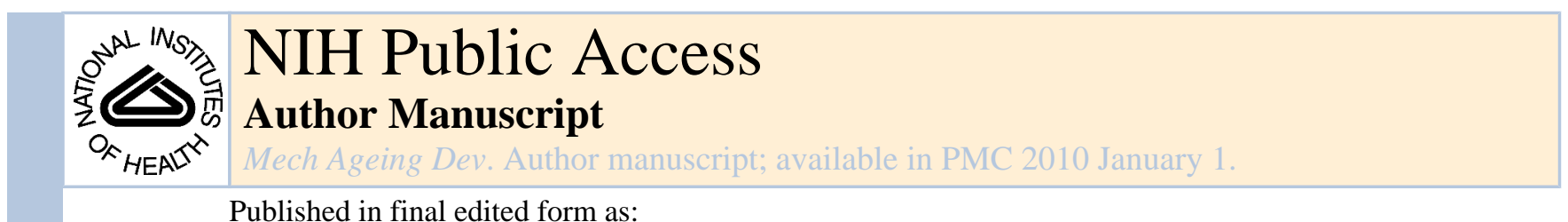

Published in final edited form as:

Mech Ageing Dev. 2009 ; 130(1-2): 10-17. doi:10.1016/j.mad.2008.06.002.

\title{
Antagonistic pleiotropy and p53
}

\author{
Erica Ungewitter and Heidi Scrable * \\ Department of Neuroscience, Health Sciences Center, University of Virginia, Charlottesville, Virginia \\ USA 22908-1392
}

\section{Introduction}

Vertebrate species demonstrate great diversity in their maximum lifespans. These can range from just 8 weeks in the coral reef pygmy goby fish (Depczynski and Bellwood, 2005) to over 175 years in giant tortoises (de Magalhaes and Toussaint, 2002). There are even rare organisms, such as members of the genus Hydra (primitive freshwater invertebrates), that display no noticeable decline in fitness with age and are believed to be biologically immortal (Martinez, 1998). However, such cases of extreme longevity are rare in the wild as starvation or predation claim most animals before they have a chance to show discernable signs of aging. For this reason, it is generally assumed that genetics does not play a significant role in the aging process. However, a clear heritable component to aging has been described for a number of organisms, including humans (Antebi, 2007; Cournil and Kirkwood, 2001; Kenyon, 2005), and there is a growing list of so-called "longevity genes".

The term "aging" is somewhat ambiguous and can refer to any change in an organism over time. For this discussion, we will define aging as the decline in the ability of an organism to maintain tissue homeostasis over time. At the molecular level, aging leads to the accumulation of cellular damage caused by various agents, such as reactive oxygen, nutritional stress, and spontaneous errors in DNA processing. Even the most basic unicellular organisms possess DNA repair machinery and antioxidant systems to protect from such damage. However, the maintenance and repair of damage to somatic cells requires significant metabolic resources (i.e. energy). The disposable soma theory of aging (Kirkwood, 1977) posits that, with a finite supply of energy, the body must compromise somatic maintenance in order to ensure reproductive success. This theory can explain why organisms that undergo rapid maturation and reach sexual maturity early in life pay for this advantage with imperfect cell and tissue repair and reduced longevity. George Williams' antagonistic pleiotropy theory of aging (Williams, 1957) proposes that cellular damage and organismal aging are caused by pleiotrophic genes, or genes with multiple phenotypic effects. Most often, these genes increase the odds of successful reproduction early in life, but have deleterious effects later in life. The harmful effects of such genes often do not become apparent until after reproduction is complete, and as a result they cannot be eliminated by natural selection.

One gene that could exhibit antagonistic pleiotropy in humans is $p 53$. p53 confers protection against cancer (and death) by interrupting the abnormal proliferation of cells. This ability to interrupt cell proliferation, however, can be deleterious when it interferes with the proliferation of normal cells, such as stem cells, which are needed for tissue renewal as the organism ages.

*Corresponding author email: hs2n@ virginia.edu.

Publisher's Disclaimer: This is a PDF file of an unedited manuscript that has been accepted for publication. As a service to our customers we are providing this early version of the manuscript. The manuscript will undergo copyediting, typesetting, and review of the resulting proof before it is published in its final citable form. Please note that during the production process errors may be discovered which could affect the content, and all legal disclaimers that apply to the journal pertain. 
Are these deleterious effects of p53 later in life the unfortunate by-products of evolving tumor suppression mechanisms to ensure the survival of the species? We review how p53 regulates gene expression in response to signals that turn on its tumor suppressor activity. We reorient these genes within the context of aging and ask if changes to p53 that have beneficial effects on tumor suppression have deleterious effects on aging. This would argue that p53 exhibits antagonistic pleiotropy. Then, we use data from recently developed models of accelerated aging in mice to determine if the deleterious effects of p53 on aging are attributable to the p53 gene or involve genes that have modifying effects on p53 activity but are evolving independently.

\section{p53 and cancer}

Human cancers have been recorded and studied for over 3500 years. Virtually every form of cancer contains clusters of affected families ( $\mathrm{Li}, 1988)$, and yet the realization that cancer is a genetic disease was made only in the middle of the last century. Li-Fraumeni syndrome, an autosomal dominant disorder characterized by greatly increased susceptibility to a variety of neoplasms, is one of the earliest examples of cancer with a clear hereditary distribution. Genetic analyses of families affected with Li-Fraumeni syndrome revealed that mutations in the coding sequence of the p53 gene co-segregated with the disease phenotype (Srivastava et al., 1990). Similar p53 mutations have been found in a majority of sporadic cancer cases, (Hollstein et al., 1991) where both biallelic inactivation and single missense mutations are associated with a variety of cancer subtypes (Tokino and Nakamura, 2000). In mice, the loss of a single functional allele of p53 significantly increases the risk of cancer and virtually every mouse with homozygous deletion of p53 develops some form of tumor at a relatively young age (Donehower et al., 1992). These data from experimental models of cancer in mice and the very large number of tumors in humans demonstrate that loss of 53 results in loss of tumor suppression.

Introduction of an additional copy of the p53 gene in mice has the opposite effect. Serrano and colleagues used bacterial artificial chromosome-based technology to insert a large fragment of DNA containing the entire p53 genomic region as a transgene. On a wild-type p53 background, these "Super-p53 mice" have three doses of the gene and an enhanced resistance to cancer compared to wild-type mice with only two doses (Garcia-Cao et al., 2002; Matheu et al., 2007). Data from this mouse model demonstrate that a gain of 53 results in an increased level of tumor suppression.

\section{p53 and aging}

The literature on p53 since it was first described in 1979 (DeLeo et al., 1979) is enormous (44,747 entries to date in PubMed), but only a small proportion of the most recent articles deals with the possibility that the activity of p53 as a tumor suppressor might be linked to aging and longevity. A phenotype of accelerated aging and reduced life span in mice was reported in 2002 in association with a mutant ("m") allele of p53 that could enhance the ability of p53 to act as a tumor suppressor (Tyner et al., 2002). The $p 53^{m}$ allele was the result of a gene targeting event in which the first six exons of full-length p53, as well as unknown upstream sequences, were deleted. Mice with one $m$ allele and one normal allele of p53 $\left(\mathrm{p} 53^{+/ m}\right)$ express the unique p53 $m$ transcript in all tissues tested. The $m$ transcript can be translated in vitro and codes for a $24 \mathrm{kDa}$ carboxyl (C)-terminal fragment of p53 (Fig. 1D). Despite intense effort, the M protein has not been detected in any tissues from $\mathrm{p} 53^{+/ m}$ mice. Expression of the full-length $\mathrm{p} 53$ protein in $p 53^{+/ m}$ mice is essentially equal to that of $p 53^{+/-}$mice, but undergoes a higher and more prolonged increase in response to ionizing radiation (Tyner et al., 2002). This is reflected in increased resistance to experimentally-induced and spontaneous tumors compared to either

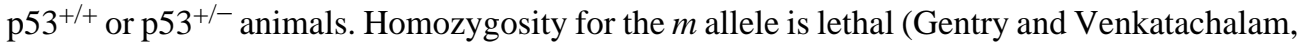
2005), in contrast to loss of both wild-type alleles. This indicates that the $m$ allele is not simply 
a null allele and that the product of $m$ acts through wild-type p53. Furthermore, it strongly argues against the possibility that genes other than p53 that were co-deleted in the recombination event play a major role in the phenotype of $\mathrm{p} 53^{+/ m}$ mice, but the possibility cannot be ruled out completely (Gentry and Venkatachalam, 2005; Vijg and Hasty, 2005).

When $\mathrm{p} 53^{+/ m}$ mice are young, they are indistinguishable from their $\mathrm{p} 53^{+/+}$littermates. However, at about 18 months of age, they begin to display progeroid symptoms, such as weight loss, lordokyphosis (hunched posture), and a general lack of vigor. Both mean and maximum life spans are significantly reduced. The mechanism underlying the accelerated aging and early death of $553^{+/ m}$ mice is not yet known. One possibility is suggested by the observation that tissues from $\mathrm{p} 53^{+/ m}$ animals, including skin, subcutaneous fat, spleen, kidney, and bone display increased atrophy and a reduced capacity for repair compared to age-matched $\mathrm{p} 53^{+/+}$tissues. This simultaneous degeneration of several different tissues could reflect a more general effect of p53 on the organism's ability to maintain tissue homeostasis as could happen, for example, if stem cells were affected. A loss of regenerative capacity in these cells would be easily explained by hyperactivity of p53 at the promoters of cell cycle arrest genes, which then would limit cell proliferation and the production of replacement cells. In fact, $\mathrm{p} 53^{+/ m}$ hematopoietic stem cells (HSC) were less able than $\mathrm{p} 53^{+/+}$HSCs to regenerate peripheral blood cells when transplanted into mice chemically depleted of endogenous HSCs (Dumble et al., 2007; Tyner et al., 2002).

The protein generated from the p53 $m$ allele lacks the activator, proline-rich, and DNA binding domains that make up the amino (N)-terminus and core of the full-length protein (Fig. 1A). This $\mathrm{M}$ protein, therefore, is unable to alter gene transcription on its own, but it can enhance the trans-activation activity of wild-type p53. Of the nine known natural isoforms of p53 (reviewed in (Murray-Zmijewski et al., 2006), the p53 ${ }^{m}$ protein is most similar in structure to $\Delta 133 \mathrm{p} 53$, which likewise contains only the tetramerization domain, basic domain, and part of the DNA binding domain (Fig. 1C). Several laboratories have shown that another naturally occurring short isoform of $\mathrm{p} 53$, which has been called $\Delta \mathrm{Np} 53$, p53/47, $\Delta 40 \mathrm{p} 53$, and $\mathrm{p} 44$ (Fig. $1 \mathrm{~B}$; we will use $\Delta 40 \mathrm{p} 53$ ), is likewise capable of altering the activity of wild-type p53 (Courtois et al., 2002; Yin et al., 2002). In the mouse, $\Delta 40$ p53 is made from the same RNA transcript as full length $\mathrm{p} 53$, but utilizes an isoform-specific internal ribosomal entry site to initiate translation at codon 41 in exon 4 (Ray et al., 2006). $\Delta 40 \mathrm{p} 53$ is $44 \mathrm{kDa}$ in size and is identical to full-length $\mathrm{p} 53$ except that it lacks the first activator domain in the $\mathrm{N}$-terminus of the protein (Fig. 1A and B; reviewed in (Scrable et al., 2005). Increased dosage of $\Delta 40 \mathrm{p} 53$ in mice with the normal complement of p53 alleles (p44Tg mice) causes premature aging similar to that of $\mathrm{p} 53^{+/ m}$ mice, with a mean lifespan of less than 16 months compared to over 20 months for nontransgenic controls (Maier et al., 2004).

In contrast to the two strains of mice in which increased tumor suppression occurs in the context of decreased lifespan, Super-p53 mice undergo a normal course of aging and have normal longevity (Garcia-Cao et al., 2002). This discrepancy can be explained by differences in the regulatory sequences that surround the $\mathrm{p} 53$ coding region in $\mathrm{p} 53^{+/ \mathrm{m}}, \mathrm{p} 44 \mathrm{Tg}$, and Super-p53 mice. In Super-p53 mice, these sequences are identical to those at the endogenous $p 53$ locus and p53 transgene expression is indistinguishable from that of endogenous p53. p53 is elevated only under circumstances of cellular stress, and (importantly) returns to low levels again when the stimulus is removed (Garcia-Cao 2002). In the case of $\mathrm{p} 53^{+/ m}$ and $\mathrm{p} 44 \mathrm{Tg}$ mice, the sequences regulating p53 are not the same as the normal p53 gene. In the case of $p 53^{m}$, a deletion has resulted in the juxtaposition of a new promoter and exon 7, and in p44Tg mice, an additional p53 coding unit has been generated in an entirely new chromosomal setting. As a result, the products of the mutant $m$ allele or $\Delta 40 \mathrm{p} 53$ are different not only in size, but also in how they are expressed under normal circumstances and when they are activated. 
In all three strains, increased activation of $\mathrm{p} 53$ results in increased expression of $\mathrm{p} 21 / \mathrm{Cip} 1 /$ Waf1, a p53 target gene (Matheu et al., 2007; Tyner et al., 2002; Maier et al., 2004). $\Delta 40$ p53 has been found to enhance the trans-activation of other p53 targets as well, including $M d m 2$ and IGFBP-3. The level of phosphorylation on $\mathrm{p} 53 \mathrm{Ser} 15$, a modification associated with activated p53 (Fiscella et al., 1993; Shieh et al., 1997), was also found to be elevated in p44Tg MEFs compared to MEFs derived from non-transgenic embryos (Maier et al., 2004). However, other p53-induced genes such as Gadd45 and PTEN were found to be down-regulated in p44Tg cells, suggesting that $\triangle 40 \mathrm{p} 53$ might alter p53 activity in a promoter-specific fashion. This hypothesis is further supported by fact that levels of the insulin-like growth factor-1 receptor (IGF-1R), which is normally transcriptionally suppressed by p53 (Werner et al., 1996), are elevated in p44Tg cells and tissues. Similar differential effects on repression and activation have been reported for human tumor-derived mutant forms of p53, which are defective at transrepressing but not trans-activating p53 targets (Ryan and Vousden, 1998). This selectivity could be due at least in part to the tetrameric structure of the active p53 transcription factor in which, presumably, all monomers that have the tetramerization domain (Fig. 1, "TD") participate (Nicholls et al., 2002). Inclusion of $\Delta 40$ p53 or any of the other p53 isoforms lacking the N-terminal region (Bourdon et al., 2005; Courtois et al., 2002; Mills, 2005) would be expected to alter co-factor binding in much the same way as the glucocorticoid receptor, another multimeric transcription factor that has numerous isoforms (see (Yudt and Cidlowski, 2002) for a review). Isoforms lacking the $\mathrm{N}$-terminus of $\mathrm{p} 53$ would also stabilize heterotetramers with full-length $\mathrm{p} 53$ by preventing proteolytic degradation mediated by Mdm2 (Michael and Oren, 2003), which binds to a site in the N-terminus of p53. The monomers themselves are much more stable than p53; for example, $\Delta 40 \mathrm{p} 53$ has a prolonged half-life of 9.5 hours, 9 hours longer than full-length p53 (Lavigueur et al., 1989). It is likely that $\Delta 40 \mathrm{p} 53$, as well as the other p53 isoforms, are capable of altering p53 activity by additional mechanisms, and these are areas of very active research.

In summary, in both p53 models with negative life span effects, a gain of p53 function results in increased tumor suppression and decreased longevity. Super-p53 mice, on the other hand, have increased tumor suppression without deleterious consequences on life span and may, in fact, live longer than wild type mice (Matheu et al., 2007). We have looked at the molecular level to determine if this reflects antagonistic pleiotropy of p53 or aberrant activity of an unlinked gene that regulates $\mathrm{p} 53$.

\section{Effectors of p53 tumor suppression}

p53 is a transcription factor that binds DNA in a sequence specific manner (Kern et al., 1992). The $\mathrm{p} 53$ protein is composed of several essential functional domains (Fig. 1). In addition to the TD mentioned previously, there is a central domain (DBD) that binds to specific DNA sequences (the so-called "p53 recognition element") in p53 target genes; the region also contains recognition motifs for protein — protein binding to cofactors such as CBP/p300 (Avantaggiati et al., 1997; Lill et al., 1997), mSin3a (Murphy et al., 1999), or TFIID (Farmer et al., 1996). The $\mathrm{N}$-terminus of p53 contains two activator domains (AD1 and AD2), which bind essential components of the transcription machinery. The $\mathrm{C}$-terminus of the protein consists of the TD and a basic domain (BD), where multiple lysine residues are subject to acetylation and ubiquitination, as well as other post-translational modifications, that regulate p53 function. The function of p53 in tumor suppression involves the trans-activation or transrepression of a large number of genes involved in cell cycle regulation and apoptosis. We will limit our discussion to two of these genes, the cyclin-dependent kinase (cdk) inhibitor p21 and the insulin-like growth factor receptor (IGF-1R). 


\section{p21/Cip1/Waf1}

p21, alternatively referred to as Cdk-interacting protein-1 (CIP1) or wild-type p53-activated fragment-1 (WAF1), is a potent mediator of both cell cycle arrest and apoptosis. The role of p21 in apoptosis is currently poorly understood due to the highly variable effects of environment and cell type on the apoptotic response (Gartel and Tyner, 2002) and will not be dealt with further in this review. Although unstressed cells can produce $\mathrm{p} 21$ by $\mathrm{p} 53$-independent methods, p53 appears to be essential for the upregulation of p21 following DNA damage (Macleod et al., 1995). Genomic integrity is maintained in proliferating cells by a series of cellcycle checkpoints, which transiently halt the cell cycle while the DNA damage is repaired. Checkpoint proteins like p21 can interact with cell cycle proteins, such as cyclin-dependent kinases (Cdks), and block the activity of cyclin/Cdk complexes. At low levels, p21 preferentially binds cdk4-6/cyclin D complexes and promotes progression to the S-phase of the cell cycle. However, when p21 levels are high, after DNA damage for example, it binds to cdk2/cyclin A-E complexes and prevents the exit from G1 into S (Chen et al., 1996; el-Deiry et al., 1994; Noda et al., 1994; Sherr and Roberts, 1999). p21 can also pause the cell cycle during S-phase by inhibiting proliferating cell nuclear antigen (PCNA), which is required for replicative DNA synthesis and DNA repair (Gartel and Radhakrishnan, 2005).

Mice lacking p21 develop normally (Deng et al., 1995), but demonstrate increased in spontaneous tumor development beginning at about 16 months of age (Martin-Caballero et al., 2001).p21 deletion accelerates the proliferation of a variety of normal cell types, including neuroblasts, forebrain stem cells, HSCs, hepatocytes, airway epithelial cells, and Sertoli cells (Blundell et al., 2004; Cheng et al., 2000; Holsberger et al., 2005; Kippin et al., 2005; Pechnick et al., 2008; Sheahan et al., 2007). However, although hematopoietic stem cells from p21deficient mice are more mitotically active than HSCs from p21+/+ mice under normal homeostatic conditions, they fail to proliferate following exposure to cell cycle-specific myelotoxic injury and are less able to repopulate the hematopoietic system of irradiated recipient mice (Cheng et al., 2000). This is because p21 maintains HSCs in a quiescent $\left(\mathrm{G}_{0}\right)$ state (Cheng et al., 2000). In the absence of p21, stem cells enter the cell cycle as transit amplifying cells, proliferate, differentiate, perform their normal functions, and then die. Failing to self-renew, they ultimately exhaust their regenerative potential. On the other hand, cancer cells lacking p21 go through the same process, but, having lost the need to self-renew, continue to proliferate indefinitely (Waldman et al., 1995). These results demonstrate that, without p21, not only would tumor risk increase, but also tissue homeostasis would be impaired as p21deficient stem cells are prematurely exhausted and the replacement cells they give rise to are depleted. Increased p21, on the other hand, would clearly be beneficial as a tumor suppressor mechanism. However, high levels of p21, although able to reduce the expansion of tumor cells, can also have the deleterious effect of inhibiting the proliferation of normal cells, for example lymphocytes (Khanna et al., 2005; Makri et al., 1998). Thus, in addition to its beneficial effects on tumor suppression, increased p21 could have deleterious effects on life span by blocking stem cell proliferation and preventing the generation of replacement cells needed to maintain tissue homeostasis.

\section{The insulin-like growth factor receptor (IGF-1R)}

The IGF-1R is a membrane-bound heterotetramer with ligand-induced tyrosine kinase capacity (LeRoith et al., 1995; Werner et al., 1989). It is constitutively expressed in most tissues and plays a central role in regulation of cell proliferation, growth, survival, differentiation, and cell motility (Larsson et al., 2005). IGF-1, and to a lesser extent, IGF-2, bind the extracellular portion of the IGF-1R and initiate a phosphorylation cascade which ultimately leads to activation of three major intracellular signaling pathways: the PI3K-AKT-mTOR/FOXO pathway; the Ras—Raf-MEK—ERK pathway; and the14-3-3 proteins (Baserga, 2000). 
The level of the IGF-1R is controlled by several tumor suppressors including WT-1, BRCA1, and p53 (Abramovitch et al., 2003; Werner et al., 1995; Werner et al., 1996). p53 suppresses IGF-1R activity by reducing endogenous levels of IGF-1R mRNA (Werner et al., 1996) and by stimulating the transcription of IGF binding protein-3 (IGFBP-3), which inhibits ligandinduced activation of the IGF-1R (Buckbinder et al., 1995). Loss of function mutations in p53 are associated with over-expression of the IGF-1R and an increased risk of tumorigenesis (Werner et al., 2000). High serum levels of the IGF-1 ligand are associated with an increased risk of prostate and breast cancers in human population studies (Renehan et al., 2004).

Furthermore, in vivo over-expression of IGF-1R accelerates the rate of tumor development and produces more invasive and distant metastases in a mouse model of pancreatic cancer (Lopez and Hanahan, 2002).

Mutations that decrease the level of the IGF-1R or block signal transduction from the receptor are tumor suppressive, but are also significant effectors of lifespan extension. Mutations in the $d a f-2$ and age- 1 genes, which are the orthologs of mammalian IGF-1R and PI-3 kinase, respectively, can extend mean lifespan in the nematode Caenorhabditis elegans by as much as $100 \%$ (Friedman and Johnson, 1988; Kenyon et al., 1993). Mutations in the Drosophila melanogaster insulin receptor, $I n R$, and in the insulin receptor substrate $C H I C O$ likewise cause significant improvements in longevity (Clancy et al., 2001; Tatar et al., 2001).

Haploinsufficiency for the $I g f-1 r$ gene or deletion of $\operatorname{Irs} 2$, which codes for insulin receptor substrate-2, confer significant increases in life span in the mouse (Holzenberger et al., 2003; Taguchi et al., 2007). And in humans, a cohort study of elderly Dutch citizens revealed that genetic variations causing reduced insulin/IGF-1 signaling were beneficial for old age survival (van Heemst et al., 2005). These data indicate that reduced IGF-IR or IGF-1 signaling, in addition to suppressing the growth of tumor cells, has beneficial effects on life span. This is different from p21, where there are beneficial effects of increased p21 on tumor suppression, but deleterious effects of increased p21 on life span.

\section{Trans-activation and trans-suppression by p53-molecular mechanisms}

The p21 promoter contains five p53 binding sites and is directly regulated by p53 (el-Deiry et al., 1993; Ocker and Schneider-Stock, 2007; Xiong et al., 1993), as illustrated in Fig. 2A. Excess p53 activity results in elevated levels of p21. This has beneficial effects on tumor suppression, but can also have deleterious effects on the proliferation of stem cells, limit the maintenance of tissue homeostasis, and provoke aging. This could be an example of antagonistic pleiotropy caused by p53.

The $I g f-1 R$ promoter has no identifiable p53 recognition sites. p53 suppresses $I g f-1 R$ transcription by sequestering TBP, the TATA-box binding subunit of the general initiation factor TFIID. The interaction of p53 with TBP blocks the formation of transcription factor complexes on the Igf-1R promoter, repressing IGF-1R transcription (Fig. 2B) (Werner et al., 1996). In the absence of p53, TBP is free to initiate IGF-1R expression (Fig. 2C). Repression of IGF-1R expression by p53 is a powerful tumor suppressor mechanism that limits the growth of tumors by blocking signal transduction cascades that turn on RNA and protein synthesis. Because decreased activity of the insulin/IGF-1 receptor signaling cascade also promotes longevity, increased p53 activity at the IGF-1R promoter would increase tumor suppression and delay aging. In this case, therefore, the effect of p53 on gene activity would not appear to exhibit antagonistic pleiotropy.

The phenotype of $\mathrm{p} 44 \mathrm{Tg}$ and $\mathrm{p} 53^{+/ m}$ mice is consistent with a model in which excess $\mathrm{p} 53$ enhances trans-activation of p21 (Fig. 2A) and elevated levels of p21 block the proliferation of both tumor cells and normal tissue stem cells. However, instead of enhancing transrepression of the Igf-1R promoter (Fig. 2B), suppressing insulin/IGF signaling, and delaying aging, excess p53 is linked to loss of trans-repression (Fig. 2C), increased insulin/IGF 
signaling, and accelerated aging. This would happen if p53 were altered in such a way that it could not interact normally with transcription complexes assembled on promoters of its target genes. It is difficult to reconcile with a model in which there was simply a change in p53 level.

\section{Switching from trans-suppressor to trans-activator}

The interactions that p53 makes with other proteins, including other transcription factors and co-factors, are dependent on post-translational modifications to the p53 protein (extensively reviewed in (Bode and Dong, 2004; Lu, 2005; Toledo and Wahl, 2006). There are currently nine recognized types of post-translational modifications to $\mathrm{p} 53$ : phosphorylation, acetylation, ubiquitination, glycosylation, ribosylation, methylation, sumoylation, neddylation, and redox regulation. These modifications are transiently conferred to $\mathrm{p} 53$ following environmental stresses, such as DNA damage, hypoxia, or nucleotide depletion. The best studied are the phosphorylated residues, which include a cluster of serines in the N-terminus (Fig. 1A, yellow symbols) associated with p53 activation and scattered sites on serines and threonines in other domains (reviewed in (Toledo and Wahl, 2006).

In the C-terminus, there is a series of lysine residues (Fig. 1A, green symbols) where acetyl groups can be added by several different histone/protein acetyl transferases (HATs): CBP/p300 (Gu and Roeder, 1997), p300/CBP associated factor (PCAF) (Liu et al., 1999), hMOF (Sykes et al., 2006), or TIP60 (Tang et al., 2006), with each HAT targeting specific residues in response to different kinds of cellular stress. For example, acetylation of Lys320 by CBP/p300 promotes the interaction of $\mathrm{p} 53$ with high-affinity binding sites regulating genes that support cell cycle arrest and survival. Acetylation of Lys 373 by the same enzyme, on the other hand, targets p53 to low-affinity binding sites, which are found in the promoters of proapoptotic genes that initiate cell death (Knights et al., 2006). Deacetylation of these and the other acetylated residues in the C-terminus of p53 is performed by histone deacetylase (HDAC)1-containing complexes (Juan et al., 2000) or by members of the silent information regulator-2 (SIR2) family of NAD + dependent HDACs (Luo et al., 2000; Vaziri et al., 2001).

There are several ways by which acetylation can alter the activity of p53. First, acetylation causes a conformational change in the protein that exposes the DNA-binding domain, thereby allowing p53 to bind target promoters (Gu and Roeder, 1997; Sakaguchi et al., 1998). Second, acetylation prevents ubiquitination by $\mathrm{Mdm} 2$ and stabilizes the protein, thereby promoting p53 activation (Liu et al., 1999). Finally, the combinatorial nature of multiple lysine residues and the modifications each combination makes to the conformation of p53 confers specificity on the choice of promoter p53 can regulate. Acetylation of p53 has been reported to increase the trans-activation capacity of $\mathrm{p} 53$ while at the same time reducing its trans-repression functions. The interaction of p53 with HATs such as CBP/p300 and PCAF is critical for trans-activation (Avantaggiati et al., 1997; Lill et al., 1997), while the association of p53 with HDACs seems to be necessary for gene trans-suppression but not trans-activation. Repression also requires an intact N-terminus (Borger and DeCaprio, 2006; Murphy et al., 1996) and the co-repressor mSin3a, which mediates the interaction of p53 with HDAC complexes (Murphy et al., 1999).

The differential effect of acetylation on suppression and activation by p53 was demonstrated for the first time on the promoters of the p21 and stathmin genes (Murphy et al., 1999; Murphy et al., 1996). DNA damage by adriamycin (doxorubicin) significantly induced expression of p21 while it suppressed expression of stathmin. Trichostatin A (TSA), a potent HDAC inhibitor, completely blocked DNA damage-induced trans-repression of stathmin (Murphy et al., 1999), but had little effect on trans-activation of p21. This difference can be explained in terms of the effect of TSA on HATs and HDACs. TSA treatment enhances the interaction between p53 and HATs, causing the level of acetylated p53 to rise and stabilizing the transcription complex (increased trans-activation). At the same time, TSA blocks the 
association of p53 with HDAC complexes, inhibiting deacetylation and preventing p53 from interrupting an active transcription complex (decreased trans-suppression). TSA has a similar effect on the p53-repressed genes Map4 (Murphy et al., 1999) and Igf- $1 R$ (Kavurma et al., 2007).

The differential effect of acetylation on $\mathrm{p} 53$ function can explain how $\Delta 40 \mathrm{p} 53$ causes both an increase in expression of the $I g f-1 R$ and an increase in the expression of $p 21$ in mice. This is illustrated in Fig. 3, where $\mathrm{S}$ represents a serine residue in the $\mathrm{N}$-terminus and $\mathrm{P}$ its phosphorylated form, and $\mathrm{K} 1$ and $\mathrm{K} 2$ represent two different acetylation sites in the $\mathrm{C}$-terminus of $\mathrm{p} 53$. In addition, $\mathrm{K} 2$ represents a site where aceylation requires prior phosphorylation in order to be acetylated. In this model, acetylation at $\mathrm{K} 1$ turns the $I g f-1 R$ promoter on, and acetylation at K2 induces expression of $p 21$. In Fig. 3A, phosphorylation of S15 promotes acetylation of $\mathrm{K} 2$ and induces expression of $p 21$. Igf- $1 R$ expression is turned off because $\mathrm{K} 1$ is deacetylated. In Fig. 3B, acetylation of $\mathrm{K} 1$ turns on $I g f-1 R$ expression. $p 21$ is not induced because S15 is dephosphorylated and K2 is deacetylated. In Fig. 3C, the conditions for acetylation to occur at both sites are met and both promoters are activated. In $\Delta 40 \mathrm{p} 53$, the critical phosphorylation site at S15 that stimulates the interaction of p53 with p300/CBP and facilitates the acetylation of certain lysine residues in the C-terminus (Lambert et al., 1998; Dumaz and Meek, 1999) is missing. In tetramers with full-length $\mathrm{p} 53$, therefore, $\Delta 40 \mathrm{p} 53$ monomers would change the availability of substrates for post-translational modifications that determine the ability of p53 to bind to a specific promoter. In response to an event that phosphorylates S15, like genotoxic stress, acetylation at sites dependent on S15 phosphorylation, like K2 in Fig. 3, would be disrupted. If K2 is the site where acetylation prevents p53 from blocking transcription of the $I g f-1 R$ gene, trans-repression would be lost and the promoter would be activated (de-repressed). Sites like K1, where acetylation is independent of S15 phosphorylation, however, would be unaffected. If K1 acetylation induces p21 expression, then even in the presence of $\Delta 40 \mathrm{p} 53$, induction would occur. The overall result would be loss of $I g f-1 R$ trans-repression and gain of $p 21$ trans-activation, which is indeed the case with p44Tg mice and cells (Maier et al., 2004). Therefore, we favor the idea that the deleterious effects on aging in these mice are due changes in post-translational modifications that interfere with the plasticity of p53 in transcription complexes. Furthermore, the association of the loss of plasticity with changes in $\Delta 40 \mathrm{p} 53$ suggests that each p53 isoform must be precisely regulated in order to maintain normal p 53 function over the lifetime of the organism.

\section{How p53 acetylation status "ages"}

If changes in post-translational modifications can affect how p53 trans-activates and transrepresses its target promoters, then age-associated changes in the enzymes responsible for modifying p53 could have deleterious effects on aging similar to those caused by $\Delta 40 \mathrm{p} 53$. One of the enzymes responsible for the acetylation state of p53 is the NAD+-dependent deacetylase SIRT1. The level of SIRT1 is regulated by a feedback loop with p53 in which p53 binds to and represses the SIRT1 promoter and SIRT1 deacetylates and inactivates p53 (Cohen et al., 2004; Nemoto et al., 2004). This feedback loop is completed by activated HATs, which reacetylate and activate p53 under conditions of genotoxic or oxidative stress (Saunders and Verdin, 2007). SIRT1 is the human homologue of Sir2, which codes for an enzyme that links replicative aging to nutrient availability in $S$. cerevisiae. Under conditions of nutrient deprivation, yeast cells stop dividing and enter a quiescent state that allows them to survive until nutrients become available again. Increased expression of SIR2 promotes increased replicative life span in yeast (Kaeberlein et al., 1999), and its orthologues, Sir2.1 in $C$. elegans and dSir2 in D. melanogaster, promote increased longevity in worms (Tissenbaum and Guarente, 2001) and flies (Rogina and Helfand, 2004). We have recently reported that mammalian cells undergoing replicative senescence, the phenomenon by which primary cells in culture lose their ability to divide (Hayflick and Moorhead, 1961), show a decline in SIRT1 
(Sasaki et al., 2006). In human fibroblasts, the levels of both HDAC1 and SIRT1 vary inversely with donor age (Kim et al., 2004). Low SIRT1 activity in human cells has been found to increase p53 acetylation, increase the expression of $p 21 \mathrm{mRNA}$, and cause premature replicative senescence (Ota et al., 2007).

In vivo, the level of SIRT1 in organs with high mitotic activity, such as the testis and thymus, declines with age (Sasaki et al., 2006). In mice exhibiting accelerated aging (such as p44Tg mice), this decrease takes place more rapidly, and in long-lived mice (such as GHRKO mice) it occurs more slowly than in mice that age normally (Sasaki et al., 2006). Emerging data suggest that manipulating SIRT1 levels in mice might increase longevity. Transgenic mice over-expressing SIRT1 appear to age like mice subjected to a regimen of calorie restriction (Bordone et al., 2007) and SIRT1 activators can ameliorate the detrimental effects on life span caused by the consumption of excess fat (the so-called "western diet") (Baur et al., 2006). These data indicate that increased SIRT1 is associated with longer life span and decreased SIRT1 with shorter life span.

The significance of these findings is that they link p53 activity and acetylation state with the level of SIRT1 and age. The effect of age on p53 or SIRT1, for example, might explain why the level of $I g f-1 R$ mRNA is higher in the hippocampus of old (29-month old) rats compared to young (2-month old) rats (Stenvers et al., 1996) or why $I g f-1 R$ expression is higher in senescent human IMR-90 fibroblasts compared to early passage cells (Chen et al., 2005). If post-translational modifications that modulate $\mathrm{p} 53$ activity change with time, then age can alter how p53 can and does respond to changes in the environment.

\section{Summary and Model}

Increased longevity is associated with increased SIRT1 (in yeast, worms, and flies) and decreased IGF-1R (in worms, flies, and mice). However, tumor suppression by p53 is enhanced by decreased SIRT1 (because acetylated p53 induces p21, for example) and decreased IGF-1R. This means that changes that decrease SIRT1 (and increase p53 acetylation) decrease the risk of developing tumors, but increase the risk of aging (Fig. 4). The deleterious effects of p53 on aging are not attributable solely to the p53 gene, but involve at least one other gene (SIRT1) that has modifying effects on $\mathrm{p} 53$ activity but is evolving independently.

\section{Acknowledgments}

We thank the members of the Scrable laboratory, both past and present, for their many contributions. This work was supported by grants from the National Institute on Aging, NIH (AG026094), and from the Ellison Medical Research Foundation.

\section{References}

Abramovitch S, Glaser T, Ouchi T, Werner H. BRCA1-Sp1 interactions in transcriptional regulation of the IGF-IR gene. FEBS Lett 2003;541:149-54. [PubMed: 12706836]

Antebi A. Genetics of aging in Caenorhabditis elegans. PLoS Genet 2007;3:1565-71. [PubMed: 17907808]

Avantaggiati ML, Ogryzko V, Gardner K, Giordano A, Levine AS, Kelly K. Recruitment of p300/CBP in p53-dependent signal pathways. Cell 1997;89:1175-84. [PubMed: 9215639]

Baserga RL. Haystacks and needles. Hum Pathol 2000;31:275-6. [PubMed: 10746666]

Baur JA, Pearson KJ, Price NL, Jamieson HA, Lerin C, Kalra A, Prabhu VV, Allard JS, Lopez-Lluch G, Lewis K, Pistell PJ, Poosala S, Becker KG, Boss O, Gwinn D, Wang M, Ramaswamy S, Fishbein KW, Spencer RG, Lakatta EG, Le Couteur D, Shaw RJ, Navas P, Puigserver P, Ingram DK, de Cabo R, Sinclair DA. Resveratrol improves health and survival of mice on a high-calorie diet. Nature 2006;444:337-42. [PubMed: 17086191] 
Blundell R, Harrison DJ, O’Dea S. p21(Waf1/Cip1) regulates proliferation and apoptosis in airway epithelial cells and alternative forms have altered binding activities. Exp Lung Res 2004;30:447-64. [PubMed: 15524404]

Bode AM, Dong Z. Post-translational modification of p53 in tumorigenesis. Nat Rev Cancer 2004;4:793805. [PubMed: 15510160]

Bordone L, Cohen D, Robinson A, Motta MC, van Veen E, Czopik A, Steele AD, Crowe H, Marmor S, Luo J, Gu W, Guarente L. SIRT1 transgenic mice show phenotypes resembling calorie restriction. Aging Cell 2007;6:759-67. [PubMed: 17877786]

Borger DR, DeCaprio JA. Targeting of p300/CREB binding protein coactivators by simian virus 40 is mediated through p53. J Virol 2006;80:4292-303. [PubMed: 16611888]

Bourdon JC, Fernandes K, Murray-Zmijewski F, Liu G, Diot A, Xirodimas DP, Saville MK, Lane DP. p53 isoforms can regulate p53 transcriptional activity. Genes Dev 2005;19:2122-37. [PubMed: 16131611]

Buckbinder L, Talbott R, Velasco-Miguel S, Takenaka I, Faha B, Seizinger BR, Kley N. Induction of the growth inhibitor IGF-binding protein 3 by p53. Nature 1995;377:646-9. [PubMed: 7566179]

Chen J, Saha P, Kornbluth S, Dynlacht BD, Dutta A. Cyclin-binding motifs are essential for the function of p21CIP1. Mol Cell Biol 1996;16:4673-82. [PubMed: 8756624]

Chen JH, Ozanne SE, Hales CN. Analysis of expression of growth factor receptors in replicatively and oxidatively senescent human fibroblasts. FEBS Lett 2005;579:6388-94. [PubMed: 16263123]

Cheng T, Rodrigues N, Shen H, Yang Y, Dombkowski D, Sykes M, Scadden DT. Hematopoietic stem cell quiescence maintained by p21cip1/waf1. Science 2000;287:1804-8. [PubMed: 10710306]

Clancy DJ, Gems D, Harshman LG, Oldham S, Stocker H, Hafen E, Leevers SJ, Partridge L. Extension of life-span by loss of CHICO, a Drosophila insulin receptor substrate protein. Science 2001;292:104-6. [PubMed: 11292874]

Cohen HY, Miller C, Bitterman KJ, Wall NR, Hekking B, Kessler B, Howitz KT, Gorospe M, de Cabo $\mathrm{R}$, Sinclair DA. Calorie restriction promotes mammalian cell survival by inducing the SIRT1 deacetylase. Science 2004;305:390-2. [PubMed: 15205477]

Cournil A, Kirkwood TB. If you would live long, choose your parents well. Trends Genet 2001;17:2335. [PubMed: 11335017]

Courtois S, Verhaegh G, North S, Luciani MG, Lassus P, Hibner U, Oren M, Hainaut P. DeltaN-p53, a natural isoform of p53 lacking the first transactivation domain, counteracts growth suppression by wild-type p53. Oncogene 2002;21:6722-8. [PubMed: 12360399]

de Magalhaes JP, Toussaint O. The evolution of mammalian aging. Exp Gerontol 2002;37:769-75. [PubMed: 12175477]

DeLeo AB, Jay G, Appella E, Dubois GC, Law LW, Old LJ. Detection of a transformation-related antigen in chemically induced sarcomas and other transformed cells of the mouse. Proc Natl Acad Sci U S A 1979;76:2420-4. [PubMed: 221923]

Deng C, Zhang P, Harper JW, Elledge SJ, Leder P. Mice lacking p21CIP1/WAF1 undergo normal development, but are defective in G1 checkpoint control. Cell 1995;82:675-84. [PubMed: 7664346]

Depczynski M, Bellwood DR. Shortest recorded vertebrate lifespan found in a coral reef fish. Curr Biol 2005;15:R288-9. [PubMed: 15854891]

Donehower LA, Harvey M, Slagle BL, McArthur MJ, Montgomery CA Jr, Butel JS, Bradley A. Mice deficient for p53 are developmentally normal but susceptible to spontaneous tumours. Nature 1992;356:215-21. [PubMed: 1552940]

Dumble M, Moore L, Chambers SM, Geiger H, Van Zant G, Goodell MA, Donehower LA. The impact of altered p53 dosage on hematopoietic stem cell dynamics during aging. Blood 2007;109:1736-42. [PubMed: 17032926]

el-Deiry WS, Harper JW, O’Connor PM, Velculescu VE, Canman CE, Jackman J, Pietenpol JA, Burrell M, Hill DE, Wang Y, et al. WAF1/CIP1 is induced in p53-mediated G1 arrest and apoptosis. Cancer Res 1994;54:1169-74. [PubMed: 8118801]

el-Deiry WS, Tokino T, Velculescu VE, Levy DB, Parsons R, Trent JM, Lin D, Mercer WE, Kinzler KW, Vogelstein B. WAF1, a potential mediator of p53 tumor suppression. Cell 1993;75:817-25. [PubMed: 8242752] 
Farmer G, Friedlander P, Colgan J, Manley JL, Prives C. Transcriptional repression by p53 involves molecular interactions distinct from those with the TATA box binding protein. Nucleic Acids Res 1996;24:4281-8. [PubMed: 8932384]

Fiscella M, Ullrich SJ, Zambrano N, Shields MT, Lin D, Lees-Miller SP, Anderson CW, Mercer WE, Appella E. Mutation of the serine 15 phosphorylation site of human p53 reduces the ability of p53 to inhibit cell cycle progression. Oncogene 1993;8:1519-28. [PubMed: 8502477]

Friedman DB, Johnson TE. A mutation in the age-1 gene in Caenorhabditis elegans lengthens life and reduces hermaphrodite fertility. Genetics 1988;118:75-86. [PubMed: 8608934]

Garcia-Cao I, Garcia-Cao M, Martin-Caballero J, Criado LM, Klatt P, Flores JM, Weill JC, Blasco MA, Serrano M. "Super p53" mice exhibit enhanced DNA damage response, are tumor resistant and age normally. Embo J 2002;21:6225-35. [PubMed: 12426394]

Gartel AL, Radhakrishnan SK. Lost in transcription: p21 repression, mechanisms, and consequences. Cancer Res 2005;65:3980-5. [PubMed: 15899785]

Gartel AL, Tyner AL. The role of the cyclin-dependent kinase inhibitor p21 in apoptosis. Mol Cancer Ther 2002;1:639-49. [PubMed: 12479224]

Gentry A, Venkatachalam S. Complicating the role of p53 in aging. Aging Cell 2005;4:157-60. [PubMed: 15924572]

Gu W, Roeder RG. Activation of p53 sequence-specific DNA binding by acetylation of the p53 Cterminal domain. Cell 1997;90:595-606. [PubMed: 9288740]

Hayflick L, Moorhead PS. The serial cultivation of human diploid cell strains. Exp Cell Res 1961;25:585621.

Hollstein M, Sidransky D, Vogelstein B, Harris CC. p53 mutations in human cancers. Science 1991;253:49-53. [PubMed: 1905840]

Holsberger DR, Buchold GM, Leal MC, Kiesewetter SE, O’Brien DA, Hess RA, Franca LR, Kiyokawa $\mathrm{H}$, Cooke PS. Cell-cycle inhibitors p27Kip1 and p21Cip1 regulate murine Sertoli cell proliferation. Biol Reprod 2005;72:1429-36. [PubMed: 15728790]

Holzenberger M, Dupont J, Ducos B, Leneuve P, Geloen A, Even PC, Cervera P, Le Bouc Y. IGF-1 receptor regulates lifespan and resistance to oxidative stress in mice. Nature 2003;421:182-7. [PubMed: 12483226]

Juan LJ, Shia WJ, Chen MH, Yang WM, Seto E, Lin YS, Wu CW. Histone deacetylases specifically down-regulate p53-dependent gene activation. J Biol Chem 2000;275:20436-43. [PubMed: 10777477]

Kaeberlein M, McVey M, Guarente L. The SIR2/3/4 complex and SIR2 alone promote longevity in Saccharomyces cerevisiae by two different mechanisms. Genes Dev 1999;13:2570-80. [PubMed: 10521401]

Kavurma MM, Figg N, Bennett MR, Mercer J, Khachigian LM, Littlewood TD. Oxidative stress regulates IGF1R expression in vascular smooth-muscle cells via p53 and HDAC recruitment. Biochem J 2007;407:79-87. [PubMed: 17600529]

Kenyon C. The plasticity of aging: insights from long-lived mutants. Cell 2005;120:449-60. [PubMed: 15734678]

Kenyon C, Chang J, Gensch E, Rudner A, Tabtiang R. A C. elegans mutant that lives twice as long as wild type. Nature 1993;366:461-4. [PubMed: 8247153]

Kern SE, Pietenpol JA, Thiagalingam S, Seymour A, Kinzler KW, Vogelstein B. Oncogenic forms of p53 inhibit p53-regulated gene expression. Science 1992;256:827-30. [PubMed: 1589764]

Khanna AK, Plummer M, Nilakantan V, Pieper GM. Recombinant p21 protein inhibits lymphocyte proliferation and transcription factors. J Immunol 2005;174:7610-7. [PubMed: 15944261]

Kim MM, Yoon SO, Cho YS, Chung AS. Histone deacetylases, HDAC1 and HSIR2, act as a negative regulator of ageing through p53 in human gingival fibroblast. Mech Ageing Dev 2004;125:351-7. [PubMed: 15130752]

Kippin TE, Martens DJ, van der Kooy D. p21 loss compromises the relative quiescence of forebrain stem cell proliferation leading to exhaustion of their proliferation capacity. Genes Dev 2005;19:756-67. [PubMed: 15769947]

Kirkwood TB. Evolution of ageing. Nature 1977;270:301-4. [PubMed: 593350] 
Knights CD, Catania J, Di Giovanni S, Muratoglu S, Perez R, Swartzbeck A, Quong AA, Zhang X, Beerman T, Pestell RG, Avantaggiati ML. Distinct p53 acetylation cassettes differentially influence gene-expression patterns and cell fate. J Cell Biol 2006;173:533-44. [PubMed: 16717128]

Larsson O, Girnita A, Girnita L. Role of insulin-like growth factor 1 receptor signalling in cancer. Br J Cancer 2005;92:2097-101. [PubMed: 15956962]

Lavigueur A, Maltby V, Mock D, Rossant J, Pawson T, Bernstein A. High incidence of lung, bone, and lymphoid tumors in transgenic mice overexpressing mutant alleles of the p53 oncogene. Mol Cell Biol 1989;9:3982-91. [PubMed: 2476668]

LeRoith D, Werner H, Neuenschwander S, Kalebic T, Helman LJ. The role of the insulin-like growth factor-I receptor in cancer. Ann N Y Acad Sci 1995;766:402-8. [PubMed: 7486685]

Li FP. Cancer families: human models of susceptibility to neoplasia--the Richard and Hinda Rosenthal Foundation Award lecture. Cancer Res 1988;48:5381-6. [PubMed: 2843281]

Lill NL, Grossman SR, Ginsberg D, DeCaprio J, Livingston DM. Binding and modulation of p53 by p300/CBP coactivators. Nature 1997;387:823-7. [PubMed: 9194565]

Liu L, Scolnick DM, Trievel RC, Zhang HB, Marmorstein R, Halazonetis TD, Berger SL. p53 sites acetylated in vitro by PCAF and p300 are acetylated in vivo in response to DNA damage. Mol Cell Biol 1999;19:1202-9. [PubMed: 9891054]

Lopez T, Hanahan D. Elevated levels of IGF-1 receptor convey invasive and metastatic capability in a mouse model of pancreatic islet tumorigenesis. Cancer Cell 2002;1:339-53. [PubMed: 12086849]

Lu X. p53: a heavily dictated dictator of life and death. Curr Opin Genet Dev 2005;15:27-33. [PubMed: 15661530]

Luo J, Su F, Chen D, Shiloh A, Gu W. Deacetylation of p53 modulates its effect on cell growth and apoptosis. Nature 2000;408:377-81. [PubMed: 11099047]

Macleod KF, Sherry N, Hannon G, Beach D, Tokino T, Kinzler K, Vogelstein B, Jacks T. p53-dependent and independent expression of p21 during cell growth, differentiation, and DNA damage. Genes Dev 1995;9:935-44. [PubMed: 7774811]

Maier B, Gluba W, Bernier B, Turner T, Mohammad K, Guise T, Sutherland A, Thorner M, Scrable H. Modulation of mammalian life span by the short isoform of p53. Genes Dev 2004;18:306-19. [PubMed: 14871929]

Makri D, Schulz WA, Grimm M, Clasen S, Bojar H, Schmitz-Drager BJ. WAF1/p21 regulates proliferation, but does not mediate p53-dependent apoptosis in urothelial carcinoma cell lines. Int $\mathrm{J}$ Oncol 1998;12:621-8. [PubMed: 9472102]

Martin-Caballero J, Flores JM, Garcia-Palencia P, Serrano M. Tumor susceptibility of p21(Waf1/Cip1)deficient mice. Cancer Res 2001;61:6234-8. [PubMed: 11507077]

Martinez DE. Mortality patterns suggest lack of senescence in hydra. Exp Gerontol 1998;33:217-25. [PubMed: 9615920]

Matheu A, Maraver A, Klatt P, Flores I, Garcia-Cao I, Borras C, Flores JM, Vina J, Blasco MA, Serrano M. Delayed ageing through damage protection by the Arf/p53 pathway. Nature 2007;448:375-9. [PubMed: 17637672]

Michael D, Oren M. The p53-Mdm2 module and the ubiquitin system. Semin Cancer Biol 2003;13:4958. [PubMed: 12507556]

Mills AA. p53: link to the past, bridge to the future. Genes Dev 2005;19:2091-9. [PubMed: 16166374]

Murphy M, Ahn J, Walker KK, Hoffman WH, Evans RM, Levine AJ, George DL. Transcriptional repression by wild-type p53 utilizes histone deacetylases, mediated by interaction with $\mathrm{mSin} 3 \mathrm{a}$. Genes Dev 1999;13:2490-501. [PubMed: 10521394]

Murphy M, Hinman A, Levine AJ. Wild-type p53 negatively regulates the expression of a microtubuleassociated protein. Genes Dev 1996;10:2971-80. [PubMed: 8956998]

Murray-Zmijewski F, Lane DP, Bourdon JC. p53/p63/p73 isoforms: an orchestra of isoforms to harmonise cell differentiation and response to stress. Cell Death Differ 2006;13:962-72. [PubMed: 16601753]

Nemoto S, Fergusson MM, Finkel T. Nutrient availability regulates SIRT1 through a forkhead-dependent pathway. Science 2004;306:2105-8. [PubMed: 15604409] 
Nicholls CD, McLure KG, Shields MA, Lee PW. Biogenesis of p53 involves cotranslational dimerization of monomers and posttranslational dimerization of dimers. Implications on the dominant negative effect. J Biol Chem 2002;277:12937-45. [PubMed: 11805092]

Noda A, Ning Y, Venable SF, Pereira-Smith OM, Smith JR. Cloning of senescent cell-derived inhibitors of DNA synthesis using an expression screen. Exp Cell Res 1994;211:90-8. [PubMed: 8125163]

Ocker M, Schneider-Stock R. Histone deacetylase inhibitors: signalling towards p21cip1/waf1. Int J Biochem Cell Biol 2007;39:1367-74. [PubMed: 17412634]

Ota H, Akishita M, Eto M, Iijima K, Kaneki M, Ouchi Y. Sirt1 modulates premature senescence-like phenotype in human endothelial cells. J Mol Cell Cardiol 2007;43:571-9. [PubMed: 17916362]

Pechnick RN, Zonis S, Wawrowsky K, Pourmorady J, Chesnokova V. p21Cip1 restricts neuronal proliferation in the subgranular zone of the dentate gyrus of the hippocampus. Proc Natl Acad Sci U S A. 2008

Ray PS, Grover R, Das S. Two internal ribosome entry sites mediate the translation of p53 isoforms. EMBO Rep 2006;7:404-10. [PubMed: 16440000]

Renehan AG, Zwahlen M, Minder C, O’ Dwyer ST, Shalet SM, Egger M. Insulin-like growth factor (IGF)I, IGF binding protein-3, and cancer risk: systematic review and meta-regression analysis. Lancet 2004;363:1346-53. [PubMed: 15110491]

Rogina B, Helfand SL. Sir2 mediates longevity in the fly through a pathway related to calorie restriction. Proc Natl Acad Sci U S A 2004;101:15998-6003. [PubMed: 15520384]

Ryan KM, Vousden KH. Characterization of structural p53 mutants which show selective defects in apoptosis but not cell cycle arrest. Mol Cell Biol 1998;18:3692-8. [PubMed: 9632751]

Sakaguchi K, Herrera JE, Saito S, Miki T, Bustin M, Vassilev A, Anderson CW, Appella E. DNA damage activates p53 through a phosphorylation-acetylation cascade. Genes Dev 1998;12:2831-41. [PubMed: 9744860]

Sasaki T, Maier B, Bartke A, Scrable H. Progressive loss of SIRT1 with cell cycle withdrawal. Aging Cell 2006;5:413-22. [PubMed: 16939484]

Saunders LR, Verdin E. Sirtuins: critical regulators at the crossroads between cancer and aging. Oncogene 2007;26:5489-504. [PubMed: 17694089]

Scrable H, Sasaki T, Maier B. DeltaNp53 or p44: priming the p53 pump. Int J Biochem Cell Biol 2005;37:913-9. [PubMed: 15743665]

Sheahan S, Bellamy CO, Dunbar DR, Harrison DJ, Prost S. Deficiency of G1 regulators P53, P21Cip1 and/or pRB decreases hepatocyte sensitivity to TGFbeta cell cycle arrest. BMC Cancer 2007;7:215. [PubMed: 18021445]

Sherr CJ, Roberts JM. CDK inhibitors: positive and negative regulators of G1-phase progression. Genes Dev 1999;13:1501-12. [PubMed: 10385618]

Shieh SY, Ikeda M, Taya Y, Prives C. DNA damage-induced phosphorylation of p53 alleviates inhibition by MDM2. Cell 1997;91:325-34. [PubMed: 9363941]

Srivastava S, Zou ZQ, Pirollo K, Blattner W, Chang EH. Germ-line transmission of a mutated p53 gene in a cancer-prone family with Li-Fraumeni syndrome. Nature 1990;348:747-9. [PubMed: 2259385]

Stenvers KL, Lund PK, Gallagher M. Increased expression of type 1 insulin-like growth factor receptor messenger RNA in rat hippocampal formation is associated with aging and behavioral impairment. Neuroscience 1996;72:505-18. [PubMed: 8737419]

Sykes SM, Mellert HS, Holbert MA, Li K, Marmorstein R, Lane WS, McMahon SB. Acetylation of the p53 DNA-binding domain regulates apoptosis induction. Mol Cell 2006;24:841-51. [PubMed: 17189187]

Taguchi A, Wartschow LM, White MF. Brain IRS2 signaling coordinates life span and nutrient homeostasis. Science 2007;317:369-72. [PubMed: 17641201]

Tang Y, Luo J, Zhang W, Gu W. Tip60-dependent acetylation of p53 modulates the decision between cell-cycle arrest and apoptosis. Mol Cell 2006;24:827-39. [PubMed: 17189186]

Tatar M, Kopelman A, Epstein D, Tu MP, Yin CM, Garofalo RS. A mutant Drosophila insulin receptor homolog that extends life-span and impairs neuroendocrine function. Science 2001;292:107-10. [PubMed: 11292875] 
Tissenbaum HA, Guarente L. Increased dosage of a sir-2 gene extends lifespan in Caenorhabditis elegans. Nature 2001;410:227-30. [PubMed: 11242085]

Tokino T, Nakamura Y. The role of p53-target genes in human cancer. Crit Rev Oncol Hematol 2000;33:1-6. [PubMed: 10714958]

Toledo F, Wahl GM. Regulating the p53 pathway: in vitro hypotheses, in vivo veritas. Nat Rev Cancer 2006;6:909-23. [PubMed: 17128209]

Tyner SD, Venkatachalam S, Choi J, Jones S, Ghebranious N, Igelmann H, Lu X, Soron G, Cooper B, Brayton C, Hee Park S, Thompson T, Karsenty G, Bradley A, Donehower LA. p53 mutant mice that display early ageing-associated phenotypes. Nature 2002;415:45-53. [PubMed: 11780111]

van Heemst D, Beekman M, Mooijaart SP, Heijmans BT, Brandt BW, Zwaan BJ, Slagboom PE, Westendorp RG. Reduced insulin/IGF-1 signalling and human longevity. Aging Cell 2005;4:79-85. [PubMed: 15771611]

Vaziri H, Dessain SK, Ng Eaton E, Imai SI, Frye RA, Pandita TK, Guarente L, Weinberg RA. hSIR2 (SIRT1) functions as an NAD-dependent p53 deacetylase. Cell 2001;107:149-59. [PubMed: 11672523]

Vijg J, Hasty P. Aging and p53: getting it straight. A commentary on a recent paper by Gentry and Venkatachalam. Aging Cell 2005;4:331-3. [PubMed: 16300486]discussion 335-8

Waldman T, Kinzler KW, Vogelstein B. p21 is necessary for the p53-mediated G1 arrest in human cancer cells. Cancer Res 1995;55:5187-90. [PubMed: 7585571]

Werner H, Hernandez-Sanchez C, Karnieli E, Leroith D. The regulation of IGF-I receptor gene expression. Int J Biochem Cell Biol 1995;27:987-94. [PubMed: 7497000]

Werner H, Karnieli E, Rauscher FJ, LeRoith D. Wild-type and mutant p53 differentially regulate transcription of the insulin-like growth factor I receptor gene. Proc Natl Acad Sci U S A 1996;93:8318-23. [PubMed: 8710868]

Werner H, Shalita-Chesner M, Abramovitch S, Idelman G, Shaharabani-Gargir L, Glaser T. Regulation of the insulin-like growth factor-I receptor gene by oncogenes and antioncogenes: implications in human cancer. Mol Genet Metab 2000;71:315-20. [PubMed: 11001824]

Werner H, Woloschak M, Adamo M, Shen-Orr Z, Roberts CT Jr, LeRoith D. Developmental regulation of the rat insulin-like growth factor I receptor gene. Proc Natl Acad Sci U S A 1989;86:7451-5. [PubMed: 2477843]

Williams GC. Pleiotropy, Natural Selection, and the Evolution of Senescence. Evolution 1957;11:398411.

Xiong Y, Hannon GJ, Zhang H, Casso D, Kobayashi R, Beach D. p21 is a universal inhibitor of cyclin kinases. Nature 1993;366:701-4. [PubMed: 8259214]

Yin Y, Stephen CW, Luciani MG, Fahraeus R. p53 Stability and activity is regulated by Mdm2-mediated induction of alternative p53 translation products. Nat Cell Biol 2002;4:462-7. [PubMed: 12032546]

Yudt MR, Cidlowski JA. The glucocorticoid receptor: coding a diversity of proteins and responses through a single gene. Mol Endocrinol 2002;16:1719-26. [PubMed: 12145329] 


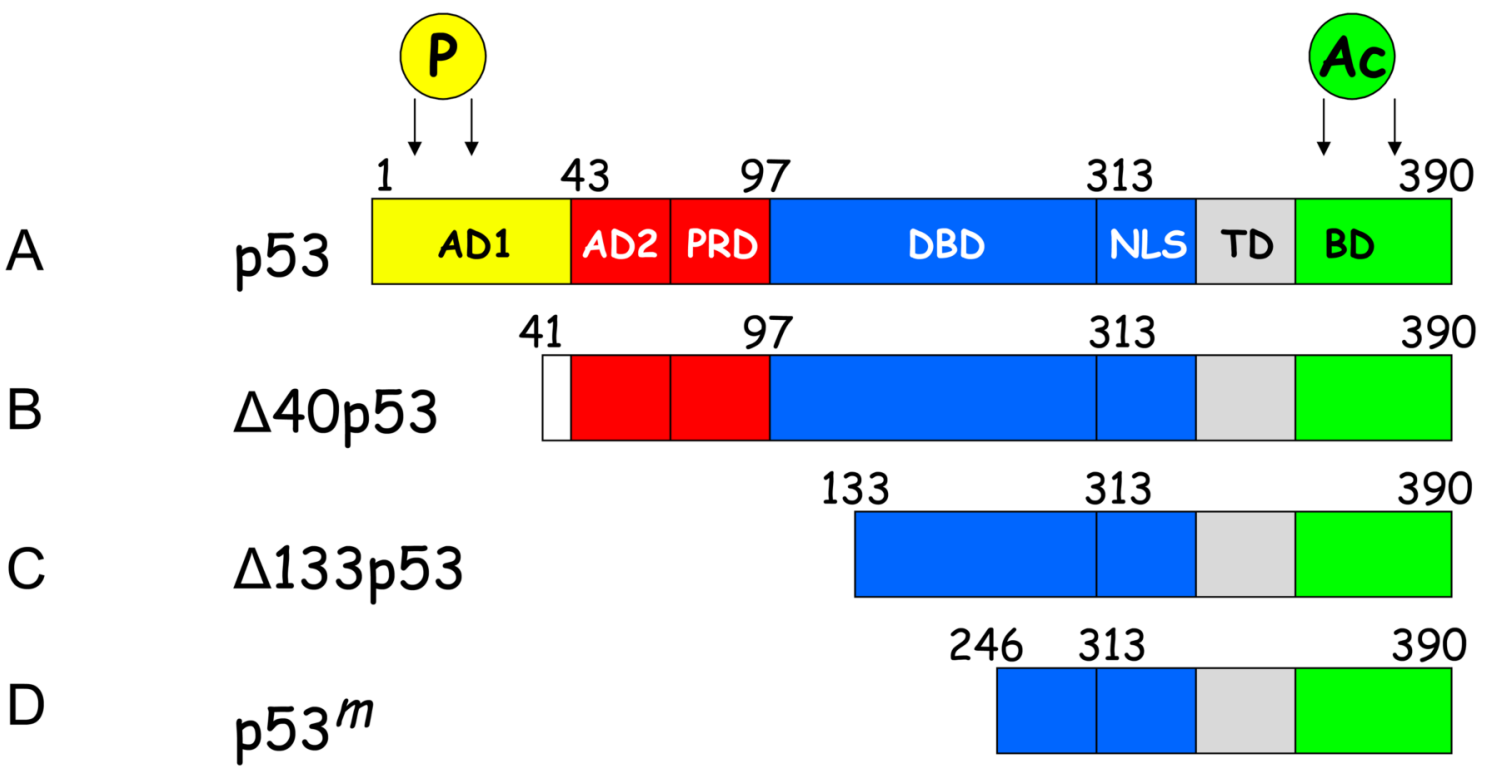

Figure 1. p53 protein isoform structure

The amino acid positions denoted above each isoform correspond to the murine protein sequence. Arrows mark the regions containing important sites for phosphorylation in the $\mathrm{N}$ terminus or acetylation in the $\mathrm{C}$-terminus for each isoform. Functional domains are coded by the following colors: activator domain 1 (AD1), yellow; activator domain 2 (AD2) and the proline-rich domain (PRD), red; DNA-binding domain (DBD) and nuclear localization signal (NLS), blue; tetramerization domain (TD), grey; and the $\mathrm{C}$-terminal basic domain (BD), green.

(A) Full-length p53 initiates at codon 1.

(B) $\triangle 40 \mathrm{p} 53$ initiates at codon 41 and is lacking most of AD1.

(C) $\triangle 133$ p53 initiates at codon 133 and lacks both AD1 and AD1, as well as the PRD and part of the DBD.

(D) The mutant protein $\mathrm{p} 53^{m}$ initiates at codon 246 . It is similar in structure to the naturallyoccurring $\triangle 133$ p53 isoform, but lacks an additional 113 amino acids from the DBD. 

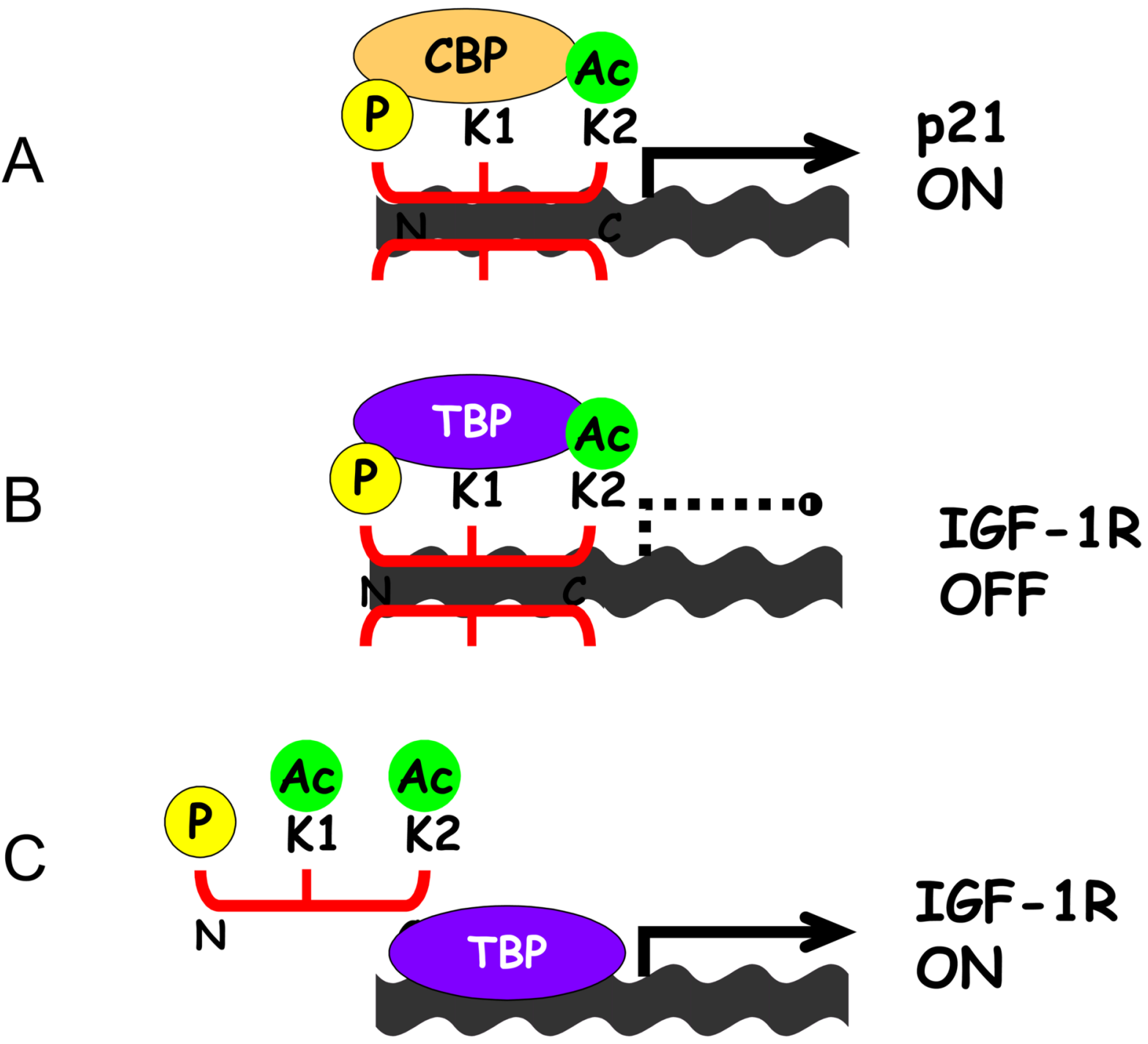

Figure 2. Target gene activation and suppression by p53 (see text for full description) The p53 protein is represented in red and post-translational modifications to the protein are shown with yellow (phosphorylated serine) or green (acetylated lysine) symbols. A) p53 binds directly to the $p 21$ promoter (grey) as a tetramer to activate p21 expression. Phosphorylation of the N-terminus and acetylation of $\mathrm{K} 2$ in the C-terminus of p53, as well as direct binding with the HAT CBP (orange) is required for this interaction.

B) p53 binds to TBP (the TATA binding subunit of TFIID; purple) and prevents transcription complex assembly on the $I g f-1 R$ promoter. This suppresses IGF-1R expression (OFF).

C) Acetylation of p53 on a different lysine residue (K1) prevents p53 from interacting with TBP and allows transcription of the IGF-1R (ON). 

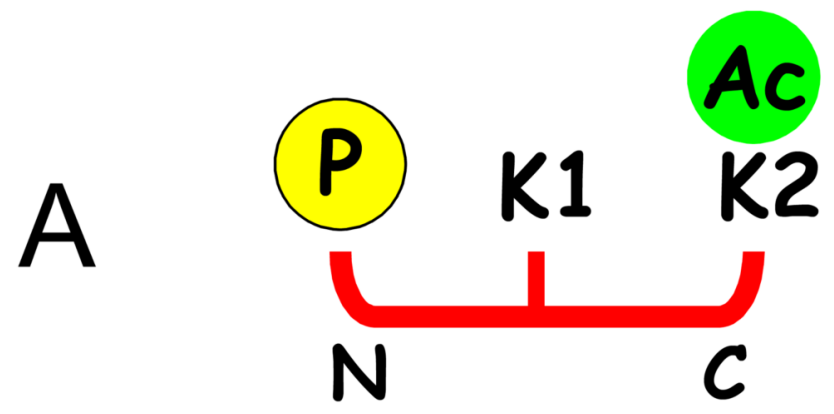

\section{p21 high Igf1r off}
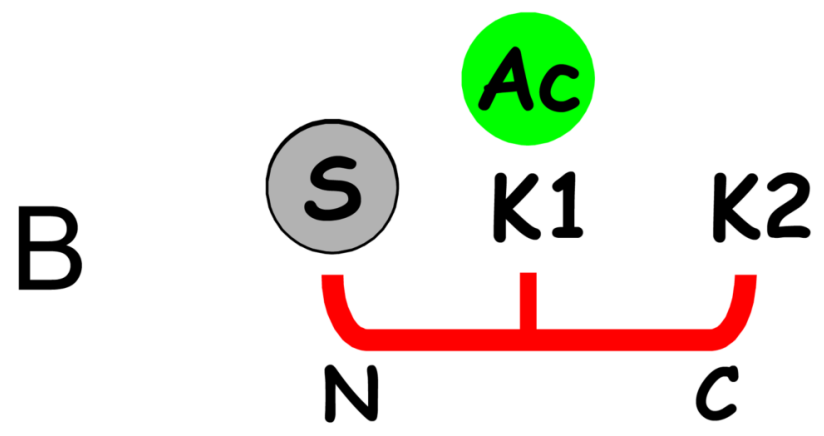

p21 low
Igf1r on

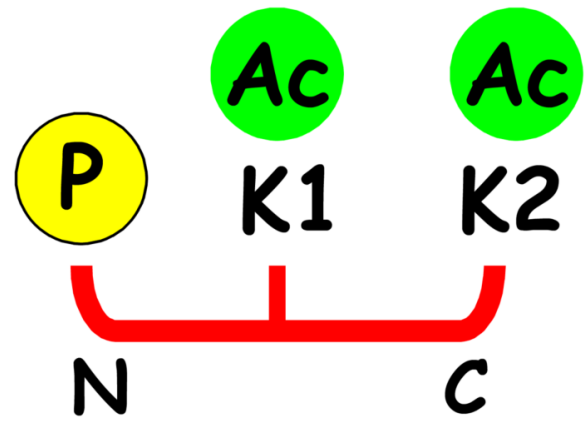

p21 high
Igf1r on

Figure 3. Acetylation has differential effects on p53 trans-activation and transsuppression (see text for full description)

The $\mathrm{p} 53$ protein is represented in red and post-translational modifications to the protein are shown with yellow (phosphorylated serine) or green (acetylated lysine) symbols.

A) Following N-terminal phosphorylation of p53, K2 is acetylated. This activates $p 21$ and suppresses $I g f-1 R$ expression.

B) In the absence of $\mathrm{N}$-terminal p53 phosphorylation, $\mathrm{K} 1$ is acetylated. This results in normal (basal) $p 21$ expression, but loss of trans-suppression (increased expression) of the Igf- $1 R$.

C) When both $\mathrm{K} 1$ and $\mathrm{K} 2$ of p53 are acetylated, there is expression of both $p 21$ and the Igf- $1 R$. 


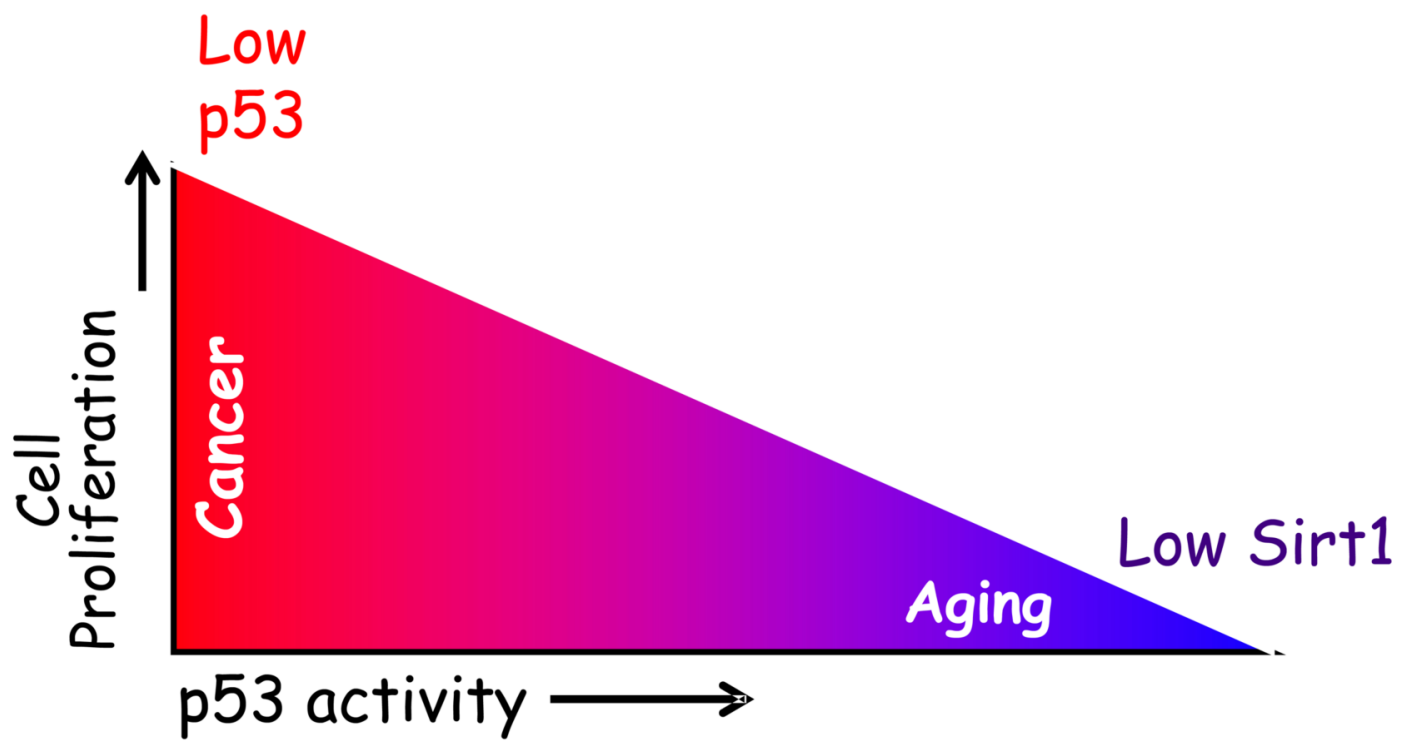

Protein level

Protein deacetylation

Figure 4. Coordinate regulation of cell proliferation by p53 and SIRT1

Model illustrating the relationship between p53 protein level, acetylation status, aging and tumor suppression. The activity of p53 ( $x$-axis) is affected by both the level of the protein (blue) and its acetylation status (red). Cell proliferation ( $y$-axis) is a function of p53 activity. Cell proliferation is high when p53 activity is low, either because the protein is scarce or because it is inactivated by SIRT1. In this situation, the risk of cancer is high. Conversely, when p53 activity is elevated due to high levels of acetylated protein, proliferation is too low to maintain tissue homeostasis and longevity is compromised. When SIRT1 activity is diminished, for example during aging, p53 will remain in its acetylated and activated state, so that even low levels of protein can lead to deleterious effects on gene expression. 